\title{
INTEGRATION CONDITIONS AND „NEW” DEVELOPMENT AND MANAGEMENT POSSIBILITIES OF REGIONAL STRUCTURES - THE IMPORTANCE OF SMART SPECIALIZATION
}

\author{
Marianna GRETA ${ }^{1 *}$, Jacek OTTO ${ }^{2 *}$ \\ ${ }^{1}$ Lodz University of Technology, Faculty of Management and Production Engineering; \\ marianna.greta@p.lodz.pl, ORCID: 0000-0003-2804-4841 \\ ${ }^{2}$ Lodz University of Technology, Faculty of Management and Production Engineering; jacek.otto@p.lodz.pl , \\ ORCID: 0000-0002-4729-3627 \\ * Correspondence author
}

Purpose: The main goal of the study is to document and attempt to assess the impact of the latest European Union development strategy, i.e. Europe 2020 Strategy. It is inextricably linked to smart specialization, development and competitive capabilities of regions of EU member states. The partial goals are:

- presenting Europe 2020 Strategy in the context of setting goals and management areas for regional policy which is part of multi-level transnational structure management in EU the Europe 2020 Strategy setting goals and management for regional policy and region will be described;

- presenting smart specialization as a result of the development of integration conditions and determining new opportunities, challenges, decision-management orders for EU regions.

Design/methodology/approach: At work, the authors mainly use source materials of European Commission, as well as foreign language studies which are also based on source material from EU institutions. Sometimes the authors had to use archival materials to take into account the value and sense of the latest integration conditions.

Findings: The work mainly shows the links between: Europe 2020 Strategy, regional policy, regions of member states, smart specialization, guidelines for multi-level management in an international structure, and practicalisation of a development strategy.

Practical implications: A member country of an integration group (EU) should be viewed in the context of an international structure and multi-level governance (including decisionmaking). The consequences of that concern the impact on the member state, on the regions, on other entities in the regions. This is mainly about implementation of knowledge, environmental protection, quality of human capital. Changes (or actually adaptations) also apply to socioeconomic development.

Social implications: The analyzes, documentation and authors' suggestions regarding mutual dependencies and connections carried out here, have an undoubted impact on society. Europe 2020 Strategy has a social dimension in all its assumptions. And they concern intelligent growth, sustainable growth, but also (above all) the growth of social integration. 
Originality/value: The study has values of originality because it goes beyond the collected materials and their presentation. The collected materials were used to capture relationships and interrelationships. A development strategy and smart specialization were used to present the latest integration conditions. Then, these conditions were presented as guidelines for multi-level governance and, consequently, for the competitiveness of European Union and its regions in the global economy.

Keywords: development strategy of the European Union, multi-level and community policy management, region - smart specialization.

Category of the paper: literature review, general review.

\section{Introduction}

Integration processes in post-war Europe, fulfilling the basic assumptions of maintaining peace in the Old Continent did not stop in place but were continuously moving towards development. It is expressed, among others in the functioning of Community policies or adopted and implemented development programs that determine the areas of management and decision-making for the Member States and their regions. The main role here goes to, among others, regional policy, which aims to alleviate the disproportion and peripherality of development and maintain the cohesion of the entire grouping. However, disparities have always accompanied the EU regions, and further extensions have made them even more prominent. The development of integration processes of the last decades has, however, led to interesting and curious searches that have been reflected, among others in long-term development programs, such as the Lisbon Strategy, or the currently implemented Europe 2020 Strategy, which will be part of our more thorough analysis. So, the Europe 2020 Strategy as a development product of integration conditions has set the main objectives of the current regional policy (2014-2020) and the challenges for its "entities", i.e. regions towards "new" development and management opportunities. These new possibilities are mainly focused on the adoption of the development strategy of the so-called Smart specialization. The preliminary considerations presented here can be illustrated in the diagram below (Figure 1). 


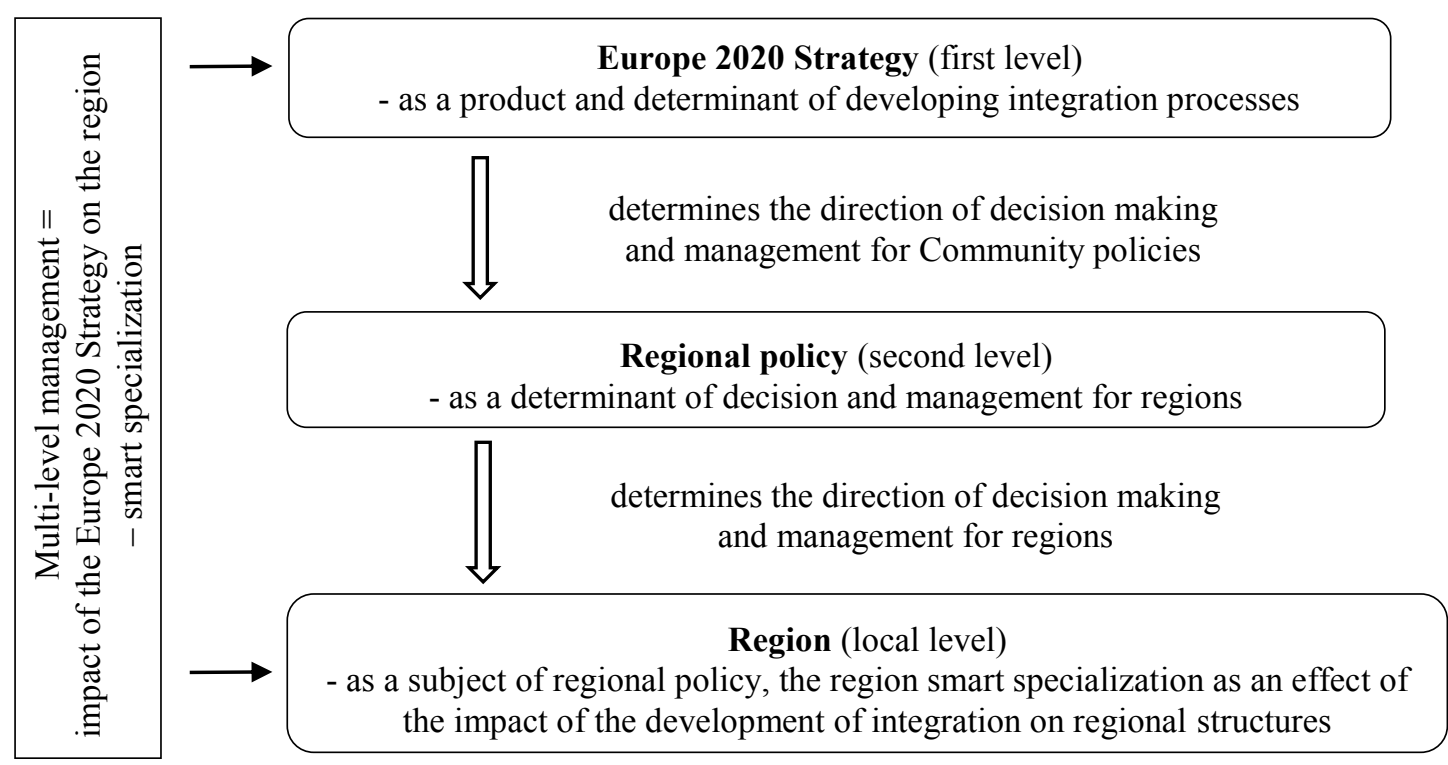

Figure 1. Mutual impact of "new" integration conditions on regional structures - smart specialization.

As it results from the above-mentioned scheme, the direct and indirect integration conditions have an impact on the development and management capabilities of the regions that are the basis of integration. The topic adopted for implementation sets the objectives and main research issues. The aim of the study is to attempt to assess the impact of smart specialization - as a result of integration development - on regional integration. The implementation of the above goal is multi-faceted and complex. However, some descriptive order was adopted in the study, namely:

- the Europe 2020 Strategy setting goals and management for regional policy and region will be described;

- the developmental essence (decision and management) of regional structures of smart specialization as a result of the development of integration conditions will be presented.

\section{The Europe 2020 strategy - as a result of the development of integration processes and a determinant for decisions and management in the regions}

The extension of integration processes from the beginning has been accompanied by development programs that include guidelines for integration and community functioning. Starting from the sixties, these were the so-called Medium-term Development Programs. After the group entered the economic and monetary union, in the last two decades, the Lisbon Strategy and its continuator in the improved version, i.e. the Europe 2020 Strategy, set the development path. This strategy contains development guidelines for EU member structures, 
i.e. countries and their regions, focusing on three levels of development and decisionmanagement regarding (Commission, 2010):

- intelligent growth;

- assumed growth;

- increase in social inclusion.

In each of these "increases" development goals are set, which in turn determine decisions and management in entities - contractors. The concept of economic and social goals within the above "three increases" is the result of the development and deepening of integration processes. And so in the context of intelligent growth, the priority is the implementation of science, in sustainable growth - security, and in the increase of social inclusion - an educated, tolerant society, employed according to the acquired qualifications. The above-mentioned goals priorityes defined the objectives in the currently implemented regional policy, that is, objectives in decisions and management in the regions. These patterns are presented in Scheme 2 below (Figure 2), while the development of the objectives of the Europe 2020 Strategy and the objectives of regional policy and interactions is described in Table 1 (Table 1).

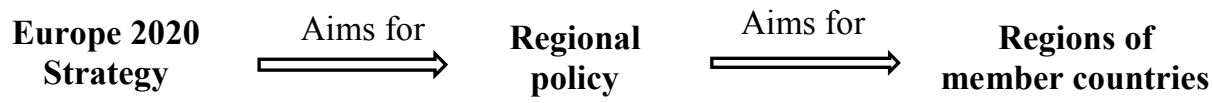

Figure 2. Europe 2020 Strategy - presence in regions.

Table 1.

Europe 2020 Strategy - goals, and regional policy 2014-2020 - goals (interconnectedness for multi-level management)

\begin{tabular}{|c|c|c|}
\hline $\begin{array}{l}\text { Goals - priorities for individual "increases" } \\
\text { in the Europe } 2020 \text { Strategy }\end{array}$ & $\begin{array}{c}\text { Types of "increases" } \\
\text { in the Europe } 2020 \\
\text { Strategy }\end{array}$ & $\begin{array}{l}\text { Objectives - priorities of } \mathrm{EU} \\
\text { regional policy in the period } \\
2014-2020 \text { - an attempt to } \\
\text { subordinate to "growths" }\end{array}$ \\
\hline $\begin{array}{l}\text { - increasing expenditures in the R\&D sphere } \\
\text { (about } 3 \% \text { of the national GDP); } \\
\text { - increasing the role of education } \\
\text { (scholarisation rate) and reducing to } 10 \% \text { the } \\
\text { number of early school leavers; } \\
\text { - an increase of up to } 40 \% \text { in the number of } \\
\text { graduates; } \\
\text { - improving the quality of education; } \\
\text { - development of digitization - digital } \\
\text { society }\end{array}$ & $\begin{array}{l}\text { Intelligent growth } \\
\mathrm{W} " 1 "-\text { transfer of } \\
\text { theoretical knowledge } \\
\text { to business practice }\end{array}$ & $\begin{array}{l}\text { 1. Research and innovative } \\
\text { activity; } \\
\text { 2. Information and } \\
\text { communication technologies; } \\
\text { 3. Competitiveness of the SME } \\
\text { sector; }\end{array}$ \\
\hline $\begin{array}{l}\text { - savings and energy security implemented } \\
\text { as } 3 \times 20 \text {, i.e.: } \\
\text { a) increase in energy efficiency by } 20 \% \text {, } \\
\text { b) an increase of } 20 \% \text { in the share of } \\
\text { renewable energy in total consumption, } \\
\text { c) a } 20 \% \text { reduction in } \mathrm{CO} 2 \text { emissions; } \\
\text { - sustainable use of resources }\end{array}$ & $\begin{array}{l}\text { Sustainable growth } \\
\text { W "2"- effective use of } \\
\text { resources and } \\
\text { increasing their } \\
\text { competitiveness }\end{array}$ & $\begin{array}{l}\text { 4. Environmental protection and } \\
\text { efficient use of resources; } \\
\text { 5. Transition to a low-carbon } \\
\text { economy; } \\
\text { 6. Adaptation to climate change } \\
\text { and risk prevention and } \\
\text { management; } \\
\text { 7. Sustainable transport and the } \\
\text { elimination of bottlenecks in key } \\
\text { network infrastructures; }\end{array}$ \\
\hline
\end{tabular}


Cont. table 1.

\begin{tabular}{|c|c|c|}
\hline $\begin{array}{l}\text { - increase in the employment rate in EU } \\
\text { countries to } 75 \% \text {; } \\
\text { - limiting unemployment (mainly young } \\
\text { people); } \\
\text { - more effective integration of legal } \\
\text { immigrants; } \\
\text { - reducing the EU population at risk of } \\
\text { poverty by } 20 \text { million; } \\
\text { - promoting social inclusion }\end{array}$ & $\begin{array}{l}\text { Increased social } \\
\text { integration } \\
\text { W "3"- increasing } \\
\text { professional efficiency } \\
\text { and fostering social } \\
\text { inclusion }\end{array}$ & $\begin{array}{l}\text { 8. Promoting employment and } \\
\text { labor mobility; } \\
\text { 9. Social inclusion and combating } \\
\text { poverty; } \\
\text { 10. Education, extending skills and } \\
\text { lifelong learning; }\end{array}$ \\
\hline Goals as above in individual increases & $\begin{array}{l}\text { Growth of ,1", ,2" } \\
\text { and ,,3" }\end{array}$ & $\begin{array}{l}\text { 11. Creating institutional } \\
\text { capabilities and effective public } \\
\text { administration; }\end{array}$ \\
\hline
\end{tabular}

Source: own elaboration based on: „Materiały Komisji Europejskiej - Polityka spójności 2014-2020. Inwestycje w rozwój gospodarczy i wzrost zatrudnienia". European Committee, Directorate for Regional Policy, Publications Office of the European Union, Luxembourg 2011, pp. 2-7; https://ec.europa.eu/commission/priorities/jobs-growth-and-investment_pl, 15.07.2019; www.euractiv.pl/ innowacyjnosc-i-kreatywnosc/artykul/strategia-ue-2020-001435, 30.12.2014; Green light to launch formal talks on EU budget for 2014-2020. https://europa.eu/rapid/press-release_MEMO-13-410_en.htm, 15.07.2019.

The management and types of decision-making in the regions (Figure 2 and Table 1) are determined by the challenges of the Europe 2020 Strategy program and concern those areas that this strategy defines for regional policy. We are dealing here (what is the domain and essence of the EU) with multi-level governance affecting regional structures, as presented in the table (Table 2).

\section{Table 2.}

Areas of impact on the region resulting from the multi-level management of the Europe 2020 Strategy and regional policy

\begin{tabular}{|c|c|c|}
\hline $\begin{array}{l}\text { Types of "growths" } \\
\text { according to table } 1\end{array}$ & $\begin{array}{l}\text { The objectives of } \mathrm{EU} \\
\text { regional policy for } 2014- \\
2020 \text { according to table } 1\end{array}$ & $\begin{array}{l}\text { Areas of action }=\text { multi-level governance in } \\
\text { regions - Europe } 2020 \text { Strategy - regional policy }\end{array}$ \\
\hline $\mathrm{W}, 1 ”$ & $1 ; 2 ; 3$ & 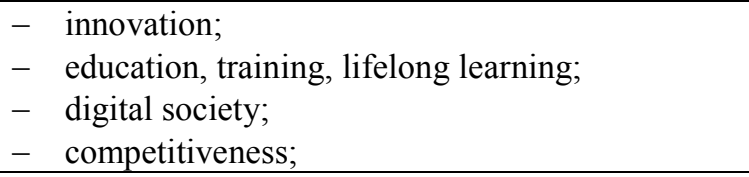 \\
\hline W „,"” & $4 ; 5 ; 6 ; 7$ & $\begin{array}{l}\text { - counteracting climate change; } \\
\text { - clean and effective energy; }\end{array}$ \\
\hline $\mathrm{W}, 3 ”$ & $8 ; 9 ; 10$ & $\begin{array}{l}\text { - } \text { employment; } \\
\text { - } \text { stimulating and strengthening skills; } \\
\text { - combating poverty }\end{array}$ \\
\hline
\end{tabular}

Source: own elaboration based on materials used in table 1.

Both the adopted Europe 2020 Strategy and the resulting objectives for regional policy and regions are the result of the development of integration processes in general, and in particular those relating to regions and directed at new development and management opportunities that relate to smart specialization. Therefore, the further part of the study will deal with this issue. 


\section{New development opportunities for regions - smart specialization}

\subsection{The essence of the concept of smart specialization}

The concept of smart specialization was developed in 2008 by a group of academic experts P.A. Dovid, D. Foray and B.H. Hall. It quickly gained supporters in the areas of theory and practice of economic life. This concept includes new possibilities and principles of defining development priorities and designating innovative areas for regional innovation policy, paying attention to the endogenous abundance of regions (Foray, Goeneg, 2013, p. 3). The development of the smart specialization concept is presented in the table below (Table 3 ).

Table 3.

What is the concept of smart specialization?

\begin{tabular}{|c|l|}
\hline No. & \multicolumn{1}{c|}{ List of the most characteristic features for smart specialization } \\
\hline 1. & $\begin{array}{l}\text { It is a concept that assumes a special understanding of the "interior" of the region in order to apply } \\
\text { appropriate support measures and is not a doctrine that imposes an absolute specialization in specific } \\
\text { industries. }\end{array}$ \\
\hline 2. & $\begin{array}{l}\text { Using bottom-up competitive advantages, it enables exploration and discovery of new technologies, or } \\
\text { development opportunities for the region, and creates new possibilities for managing it. }\end{array}$ \\
\hline 3. & $\begin{array}{l}\text { Specializations are based on vertical intervention logic i.e. aid funds go there to those areas and areas } \\
\text { whose identification will be compatible with the possibilities, needs and potential expectations for } \\
\text { benefits, i.e. the use of the smart specialization philosophy can lead to the development of endogenous } \\
\text { advantages, even the weaker regions, which until now, were the proverbial "Achilles' heel" of European } \\
\text { regional policy. }\end{array}$ \\
\hline 4. & $\begin{array}{l}\text { According to the European Commission, smart specialization is subject to specific structuring of } \\
\text { Community policies (regional, agricultural, industrial, scientific and research) in order to identify and } \\
\text { promote new development opportunities of regions based on endogenous wealth of regions, knowledge } \\
\text { and innovation. Determinants of smart specialization are, among others: } \\
-\quad \text { availability; } \\
-\quad \text { absorption; } \\
-\quad \text { the spread of innovation; } \\
-\quad \text { using the accumulated knowledge and entrepreneurship; } \\
-\quad \text { contacts with business partners and support of local authorities. }\end{array}$ \\
\hline 5. & $\begin{array}{l}\text { It guarantees high standards of services, followed by the creation of clusters and industry parks as well } \\
\text { as attracting new contractors, which could act as so-called "Great thrust" in regional development. }\end{array}$ \\
\hline
\end{tabular}

Source: own elaboration based on: „The goals of smart specialisation” by D. Foray, X. Goeneg. 2013. S3 Policy Brief Series, 01, p. 4 and further; „Doktryny zjednoczeniowe Ojców Europy drogą do pogłębionej integracji (Smart Specialization). Wielkie nazwiska - wielkie marki, Watykan o zjednoczonej Europie" by M. Greta, J. Kowalski, E. Tomczak-Woźniak. 2018. Łódź: Wydawnictwo Politechniki Łódzkiej, pp. 24-28.

The specificity and philosophy of the above concept is the search for new directions of development for regions and the search for and the use of their endogenous advantages. Thus, it is possible to find many similarities to Ricardian theory of comparative costs in this concept. Smart specialization is directed, however, to all regions, both the technological leaders, i.e. innovators, and those following the ,development tails". And it seems that in the peripheral areas it is of particular importance for these regions to be "drawn out" from the proverbial development backwater and to give opportunities to backward and peripheral regions to establish contact with development centers, or centers of growth. Here, there may be 
a discussion that the innovator will still be in the lead, and the weak region - despite smart specialization - will still be in a worse position. However, it should be noted that thanks to this specialization, the "chasing" position is significantly improving, and the EU also supports it with special structural assistance e.g. through the Connecting Europe instrument or within the European Territorial Cooperation. It is also worth noting that this concept in the light of theory was born in Italy, meaning in a country with large regional spans. It was, however, its rebirth, a return to its essence, because earlier elements of such specialization can already be observed in A. Marshall, among others in his theory of industrial districts (Marshall, 1947, pp. 25-46), and in particular in the theory of new industrial districts (Scott, 1988, pp. 3-18; Storper, 1997, pp. 21-29). A particularly important contribution to the development of specialization as a regional development path comes from studies referring to Italian districts, which were based on the specialization and cooperation of companies from labor-intensive and low-tech industries (Bagnasco, 1977, pp. 11-29; Becattini, 1989, pp. 111- 128, Piore, Sabel, 1984; Becattini, 1987, pp. 33-60). In the new edition, it "came alive" on the path from districts to clusters - grapes (e.g. with M.E. Porter) or to the learning region (e.g. with R. Florida) in search of factors of regional development (Florida, 1995; Storper, 1997).

\subsection{European Union in relation with smart specialization - selected issues}

The adaptation of smart specialization in the EU is the result of deepening of integration processes on the one hand, and the adopted solutions, development programs and implemented community policies on the other. This is because the deepening of integration increasingly emphasizes the development differences, but at the same time the Europe 2020 Strategy, or the current regional policy have, in a sense, to control these differences to prevent their deepening. Will smart specialization meet this requirement? This cannot be foreseen to the end, and opinions among the theoreticians are strongly divided. It is a fact, however, that the EU is undertaking - through smart specialization - another attempt to equalize economic and social disproportions between regions of different speeds. Certainty is not whether the implementation of smart specialization is a panacea for regional disparities, but it is certainly at least temporarily, in a given time the region will be noticed.

Researchers and scientists from the University of Maastricht $-\mathrm{R}$. Wintjes and H. Hollanders - preparing a report for the EU entitled "Innovation pathways and Policy challenges at regional level: smart specialization" prove that the position of regions and their openness to innovation depend on three factors:

- access to knowledge;

- the region's ability to absorb this knowledge;

- spreading knowledge and technology.

And in view of the above, they divided EU regions into seven groups (Wintjes, Hollanders, 2011). Further information on this subject is included in the table (Table 4). 
Table 4.

Factors of regional development and division of European Union regions in the context of smart specialization according to $R$. Wintjes and H. Hollanders

\begin{tabular}{|c|c|c|}
\hline No. & $\begin{array}{l}\text { The type of regional } \\
\text { development factor }\end{array}$ & Characteristics of a given regional development factor \\
\hline 1 & $\begin{array}{l}\text { Region availability to } \\
\text { knowledge }\end{array}$ & $\begin{array}{l}\text { It means connections in the region, both communication routes, information } \\
\text { flow channels as well as business connections networks with cities, other } \\
\text { regions or even countries. This availability depends primarily on local } \\
\text { infrastructure, distance from markets, population density, knowledge } \\
\text { infrastructure and innovation in the level of development of the regional R\&D } \\
\text { sphere. }\end{array}$ \\
\hline 2 & $\begin{array}{l}\text { Absorbency and } \\
\text { openness of the region } \\
\text { for knowledge }\end{array}$ & $\begin{array}{l}\text { This factor is closely related to the presence in the region of people with } \\
\text { appropriate qualifications and equipment of the region with appropriate } \\
\text { specialist equipment, as well as a broadly expanded service market. }\end{array}$ \\
\hline & $\begin{array}{l}\text { Spreading knowledge } \\
\text { and technology }\end{array}$ & $\begin{array}{l}\text { It involves the distribution of technologically advanced products on local } \\
\text { markets, the flow of knowledge, professional contacts, migrations of } \\
\text { specialists from the region to the region with high qualifications, or the } \\
\text { migration of these specialists between different areas of technology. }\end{array}$ \\
\hline 4 & \multicolumn{2}{|c|}{$\begin{array}{l}\text { EU regions according to R. Wintjes and H. Hollanders in the context of the above factors: } \\
-\quad \text { metropolises, centres of services saturated with knowledge; } \\
-\quad \text { regions that absorb knowledge; } \\
-\quad \text { public knowledge centres; } \\
-\quad \text { industrialized regions of Eastern Europe; } \\
-\quad \text { technologically advanced regions; } \\
-\quad \text { traditional southern regions. }\end{array}$} \\
\hline
\end{tabular}

Source: own work on the basis of: 4. "Innovation pathways and policy challenges at the regional level: smart specialization" by Wintjes, R., Hollanders H. 2011. MERIT Working Papers from United Nations University - Maastricht Economic and Social Research Institute on Innovation and Technology (MERIT), 27; "Euroregiony polskie w procesie integracji europejskiej oraz w przezwyciężaniu peryferyjności i dysproporcji regionalnych" by M. Greta. 2013 Łódź: Wydawnictwo Uniwersytetu Łódzkiego, pp. 121-123.

The report shows that the concept of dividing the EU regions of Wintjes and Hollanders according to the accessibility to knowledge, absorption and spread of innovation "does not eliminate from the game" weak and peripheral regions giving them hope for development opportunities using smart specialization. Distinguishing of the size of regions (Table 4) breaks with the classic division into the development centre and peripheries. Such a distinction creates wider opportunities for interregional cooperation in discovering their internal development opportunities.

Intelligent specialization and the discovery of internal development opportunities of regions is facilitated by the Europe 2020 Strategy (point 2 of this study), which assumes intelligent development with energy security and high qualifications as well as labor mobility. The EU favours smart specialization, as evidenced by the thematic reports as well as the adopted guidelines in development strategies. Taking into account both of them (theoretical guidelines and programs for practice), it should be emphasized that the economic development of the EU takes into account the development triad, i.e. economy, science and education, taking into account the role of regions in this process (point 2 of the study). The EU's developmental goals in the near future will certainly dominate smart specialization, because at least until 2020, EU priorities in the Europe 2020 Strategy and Community policies as well as in structural funds and all available financial instruments are known. It was not without significance that the new 
instrument "Connecting Europe" was adopted for regional policy for 2014-2020. It is a kind of "utility" for the extension of smart specialisation, because this instrument goes to the outermost peripheral regions financing transport, energy and digitalisation. The above-mentioned instrument, emphasizing three different sectors, i.e. smart, sustainable and interconnected transport, energy and digital networks, is not only passive aid for peripheral regions, but also a kind of financial catalyst to stimulate interest in the internal capabilities of weak regions and mobilize other sources of funding (e.g. from public or private sources). The actions of the Connecting Europe tool itself have a more macro-oriented focus, i.e. the creation of a European network connecting major socio-economic centres and development gates, e.g. ports, other air, water or land connections, or creating a key infrastructure to strengthen the single market and its competitiveness. However, this macro impact serves the discovery of peripheral regions, i.e. it serves the micro dimension, and, as a consequence, the uncovered region can "surrender" to smart specialization. Thus, the Europe 2020 Strategy "grows into" regional policy objectives for the period 2014-2020, and these objectives affect the modification and differentiation of existing sources of structural assistance funding, among which the Connecting Europe tool marked its own presence, which can be more graphically traced with the help of the following scheme (Figure 3).

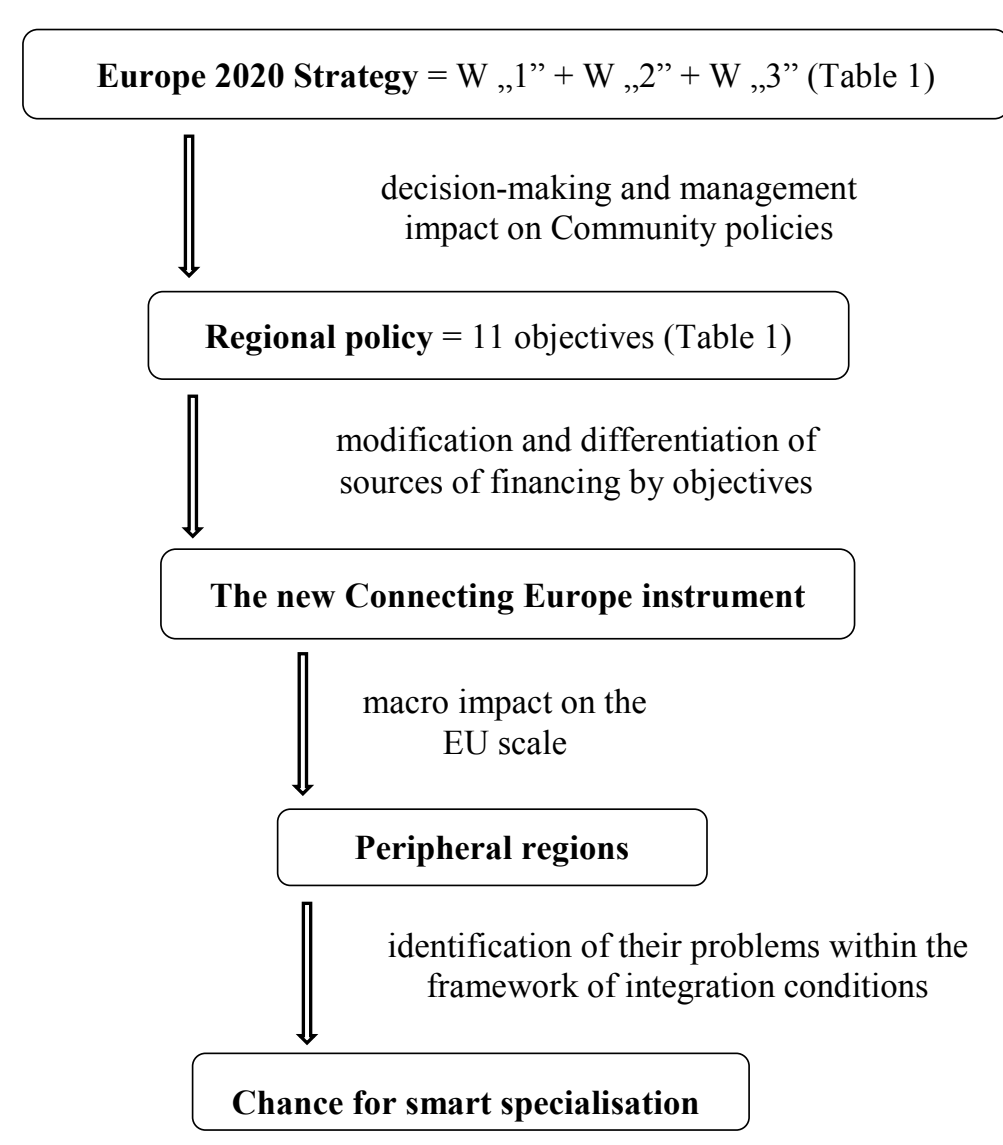

Figure 3. European Union in relation to smart specialization - selected issues. Own elaboration on the basis of: "Euroregiony polskie w procesie integracji europejskiej oraz w przezwyciężaniu peryferyjności i dysproporcji regionalnych" by M. Greta. 2013 Łódź: Wydawnictwo Uniwersytetu Łódzkiego, pp. 117-119. 
Analysing the above scheme, one can conclude that the EU reacts to smart specialization, which is reflected in general actions undertaken (development strategies, regional policies) or specific ones referring to the introduction of specialist financial instruments. Point 3.2 of this study also cites the division into regions in the EU, which in its assumptions does not serve regional diversification, but as a consequence is to help to define regional differences and their mitigation. Some selected issues indicated here are the result of a deepening of the integration processes within the framework of the economic union and serve to achieve social and economic cohesion within the integration group. In these processes the region with its internal resources plays an important role, and if the region decides to go with smart specialisation, it undoubtedly has an impact on the decision-making and management structures resulting from the undertaken developmental specialization. There are such organizational structures in the region that direct smart specialization, for example, it is particularly visible in specific regions, e.g. in Euroregions.

\section{Conclusion}

Both the Europe 2020 Strategy and its main implementer, i.e. regional policy together with the contractor entities (regions) result from the deepening of integration processes and development challenges that the EU faces in the 21 st century. On the one hand, regions evolve under the influence of deepening integration, and on the other, integration is evolving under the influence of subsidiarity in the regions. And it is the smart specialization that expresses such subsidiarity by orientating the region to endogenous development factors and their effective use. The adoption and implementation of the above specialization is a way to look for development opportunities for regions, while prioritizing the equalization of socio-economic disparities in the regions of "different speeds". The smart specialization is introduced in the expectation that the weaker regions will be able to catch up with the developed regions using their internal potential.

On the one hand, one should look optimistically at this specialization, because in the era of the information society, the use of technological development combined with intraregional wealth can contribute to regional development and accelerate the pace of absorption of technological innovations. On the other hand, one should bear in mind the fact that the more developed regions "will not stand still" waiting for the effect of catching up with the weaker ones. Therefore, there may be a kind of technological gap between regions, but smart specialization offers the possibility of reducing this gap, especially as it has specific financial means at its disposal, available only for weak regions. Therefore, according to the authors, even a primitive region can be intelligently specialized, because in the region one can choose, for example, a unique and practically desirable direction of specialization, and when internal 
factors are favourable, there is no need to import them from the outside, e.g. specialization of the region in ecological agricultural production, in special types of tourism, or specialization taking into account the unique qualities of national heritage. This is particularly important for the regions of Central and Eastern Europe (classification according to Table 4), since most of these areas belong to the technological periphery, and through smart specialization can enter into "possession" of special structural assistance. There are positives as well as negatives of such specialization, although today more considered in the light of theory, because practical effects should be expected in accordance with the laws of economy only after a longer period of time. However, it seems certain - thanks to smart specialization - the acquisition of new organizational and decision-management skills in the region, which will be managed as part of national economic activities and policy, and will be subject to multilevel governance as part of the EU's Community strategies and policies, as well as in part within the EU institutional system.

\section{References}

1. Bagnasco, A. (1984). Tre Italie. Bologna: Il Mulino.

2. Becattini, G. (1989). Riflessioni sul distretto industriale marshalliano come concetto socioeconomico. Stato e Mercato, 25.

3. Becattini, G. (Ed.) (1987). Mercato e Forze Locali: Il Distretto Industriale. Bologna: Il Mulino.

4. Florida, R. (1995). Toward the Learning Region. Future, 5(27).

5. Foray, D., Goeneg, X. (2013). The goals of smart specialisation. S3 Policy Brief Series, 1.

6. Green light to launch formal talks on EU budget for 2014-2020, https://europa.eu/rapid/ press-release_MEMO-13-410_en.htm, 15.07.2019.

7. Greta, M. (2013). Euroregiony polskie $w$ procesie integracji europejskiej oraz $w$ przezwyciężaniu peryferyjności $i$ dysproporcji regionalnych. Łódź: Wydawnictwo Uniwersytetu Łódzkiego.

8. Greta, M., Kowalski, J., Tomczak-Woźniak, E. (2018). Doktryny zjednoczeniowe Ojców Europy droga do pogłębionej integracji (Smart Specialization). Wielkie nazwiska - wielkie marki, Watykan o zjednoczonej Europie. Łódź: Wydawnictwo Politechniki Łódzkiej.

9. http://www.euractiv.pl/innowacyjnosc-i-kreatywnosc/artykul/strategia-ue-2020-001435, 30.12.2014.

10. https://ec.europa.eu/commission/priorities/jobs-growth-and-investment_pl, 15.07.2019.

11. Komisja Europejska (2010). Komunikat Komisji: Europa 2020. Strategia na rzecz inteligentnego i zrównoważonego rozwoju sprzyjającego właczeniu społecznemu. Bruksela: KOM. 
12. Marshall, A. (1947). Principles of Economics, An introductory volume. London: Macmillan.

13. Materiaty Komisji Europejskiej - Polityka spójności 2014-2020. Inwestycje w rozwój gospodarczy $i$ wzrost zatrudnienia (2011). Komisja Europejska, Dyrekcja ds. Polityki Regionalnej, Urząd Publikacji Unii Europejskiej, Luksemburg.

14. Piore, M., Sabel, C. (1984). The second Industrial Divide. New York: Basic Book.

15. Scott, A.J. (1988). New Industrial Spaces: Flexible Production Organization and Regional Development in North America and Western Europe. London: Pion.

16. Storper, M. (1997). The Regional Word: Territorial Development in a Global Economy. New York: The Guilford Press.

17. Wintjes, R., Hollanders, H. (2011). Innovation pathways and policy challenges at the regional level: smart specialization. MERIT Working Papers from United Nations University - Maastricht Economic and Social Research Institute on Innovation and Technology (MERIT), 27. 